\title{
Evaluation of Albumin, Zinc and Vitamin C in Surgical Wound
}

\section{Patients}

\author{
Nnodim Johnkennedy ${ }^{1 *}$, Nwobodo Emmanuel ${ }^{2}$, Nwadike Constance ${ }^{1}$, Edward Ukamaka ${ }^{1}$, Aloy-Amadi \\ Oluchi $^{1} \&$ Obi Patrick ${ }^{3}$ \\ ${ }^{1}$ Department of Medical Laboratory Science, Faculty of Health Science, Imo State University Owerri, \\ Imo State, Nigeria \\ ${ }^{2}$ Department of Biochemistry, Chukwuemeka Odumegwu Ojukwu University Uli Anambra State, \\ Nigeria \\ ${ }^{3}$ Federal Medical Centre Owerri Imo State, Nigeria \\ *Nnodim Johnkennedy, E-mail: johnkennedy23@yahoo.com
}

Received: April 8, 2017

doi:10.22158/mshp.v1n2p60
Accepted: April 19, 2017

Online Published: April 20, 2017

URL: http://dx.doi.org/10.22158/mshp.v1n2p60

\section{Abstract}

The serum albumin, zinc and vitamin C statuses of surgical wound patients attending General Hospital Owerri, Nigeria were investigated to determine whether or not the serum levels of these elements were normal. One hundred surgical wound patients age 20-40 years were selected. One hundred normal subjects age 20-40 years were used as control. The levels of albumin, zinc and vitamin $C$ were significantly decreased in surgical wound patients, when compared with the control $(p<0.05)$. The result suggests, but not conclusively, that supplementation of surgical wound patients, with food and drug containing albumin, zinc and vitamin $C$ might be helpful, particularly for the healing $f$ surgical wounds.

\section{Keywords}

albumin, zinc and vitamin $C$

\section{Introduction}

A surgical wound is referred as a cut or incision in the skin that is usually made by a scalpel during surgery. It can also be the result of a drain placed during surgery (Waldrop et al., 2000). Surgical wounds vary in sizes. It is crucial to note that the surgical wounds are usually closed with sutures, but are sometimes left open to heal. It can be grouped into four categories. These groups depend on how contaminated or clean the wound is, the risk of infection, and where the wound is located on the body (Coello et al., 2005). Group one is considered clean wounds. They show no signs of infection or inflammation. They often involve the eye, skin, or vascular system, while group two is considered 
clean-contaminated. Although the wound may not show signs of infection, it is at an increased risk of becoming infected because of its location. For example, surgical wounds in the gastrointestinal tract may be at a high risk of becoming infected (Culver et al., 2005). However, group three is surgical wound in which an outside object has come into contact with the skin having a high risk of infection and is considered a contaminated wound. For example, a gunshot wound may contaminate the skin around where the surgical repair occurs. Group four is class of wound considered dirty-contaminated. These include wounds that have been exposed to fecal material. Surgical wounds are created when a surgeon makes an incision or cut with a surgical instrument called a scalpel. A wide variety of medical circumstances require surgery. The size of a wound depends on the type of procedure and location on the body. Any surgical procedure will create a surgical wound. The likelihood of a wound infection after surgery is between 1 and 3 percent. The risk factors for developing a surgical wound infection include having other medical issues, such as diabetes or a weakened immune system. Smokers, older adults, and people who are overweight also have an increased risk of infection. Emergency surgeries, abdominal surgeries, and surgeries that last longer than two hours could result to a higher risk of infection (Velnar et al., 2009; Hunt et al., 2000).

The signs of a surgical wound infection include increased pain and redness around the wound, delayed healing, the presence of pus, a foul smell, or drainage from the wound. In some cases, an infected surgical wound can appear dried out or deeper. Fever may also be a common symptom (Rivera \& Spencer, 2007)

One of the common nutritional problems among surgical wound is albumin disorder. Albumin is the most abundant protein in human blood plasma; it constitutes about half of serum protein (Kuzuya et al., 2007). It is synthesized in the liver. It transports hormones, fatty acids, and other compounds, buffers $\mathrm{pH}$, and maintains oncotic pressure, among other functions. Albumin is synthesized in the liver as preproalbumin, which has an $\mathrm{N}$-terminal peptide that is removed before the nascent protein is released from the rough endoplasmic reticulum (Numeroso et al., 2008). The product, proalbumin, is in turn cleaved in the Golgi vesicles to produce the secreted albumin. Serum albumin is considered as a measure of inflammation, and is usually used for the assessment of inflammatory state as well as prediction of treatment response. Among the parameters of inflammation, low serum albumin is of particular importance, because it is a reflection of nutritional status and inflammation (Graham et al., 2007). It is a marker of protein-energy wasting and a component of Malnutrition-Inflammation Complex (MIC) (Agwaral et al., 2008; Behzad et al., 2015).

Zinc is an essential mineral perceived by the public as being of exceptional biologic and public health importance, especially regarding prenatal and postnatal development (Nnodim et al., 2014a). Most zinc is in the brain, muscle, bones, kidney, and liver, with the highest concentrations in the prostate and parts of the eye. Semen is particularly rich in zinc, a key factor in prostate gland function and reproductive organ growth (Hambidge \& Krebs, 2007).

In humans, the biological roles of zinc are ubiquitous. It interacts with a wide range of organic ligands, 
and has roles in the metabolism of RNA and DNA (Atakisi et al., 2009).

Vitamin C is very necessary in Surgical wound patients. Vitamin C is a water-soluble vitamin. It is gotten from citrus fruits, broccoli, and tomatoes (Zainab, 2003). Vitamin C is needed for the growth and repair of tissues in all parts of the body. It helps the body makes collagen, an important protein used to make skin, cartilage, tendons, ligaments and blood vessels. Vitamin $\mathrm{C}$ is needed for healing wounds, and for repairing and maintaining bones and teeth. It also helps the body absorb iron from nonheme sources (Titus et al., 2004).

Vitamin $\mathrm{C}$ is an antioxidant, along with vitamin $\mathrm{E}$, beta-carotene, and many other plant-based nutrients. Antioxidants block some of the damage caused by free radicals, substances that damage DNA (Mauro, 2006; Nnodim et al., 2014b).

Owing to scarcity of information on albumin, zinc and vitamin $\mathrm{C}$ statuses, this study tends to evaluate these biochemical parameters among surgical wound patients visiting General Hospital Owerri, Imo State Nigeria.

\section{Method}

\subsection{Subjects}

Hundred surgical wound patients (50 males and 50 females) aged 20-40 years were selected for the study. One hundred normal subjects (50 males and 50 females) were used as control.

\subsubsection{Blood Sample}

In all subjects, $5 \mathrm{ml}$ of venous blood was collected into a non-anticoagulated tubes. The sample were spun in a Wisterfuge (model 684), centrifuge at $1000 \mathrm{~g}$ for 10 minutes and the serum collected into a clean dry bijou bottle. The albumin, zinc and vitamin $\mathrm{C}$ were estimated.

Informed consent of the participants was obtained and was conducted in line with the ethical approval of the hospital.

\subsubsection{Biochemical Assay}

Albumin was determined by Bromocresol method. Zinc level was determined by atomic absorption spectrophotometer technique as described by Kaneko (Kaneko, 1999). Serum Vitamin C was determined by the 2, 4-dinitrophnyl hydrazine method described by Tietz (1976).

\subsubsection{Statistical Analysis}

The results were expressed as mean \pm standard deviation. The statistical evaluation of data was performed by using students t-test. The level of significance was calculated at $\mathrm{P}<0.05$.

\section{Result}

Table 1. Albumin, Zinc and Vitamin C Level in Surgical Wound Patients and Control

\begin{tabular}{lll}
\hline PARAMETERS Control surgical wound patients &
\end{tabular}




\begin{tabular}{llll}
\hline Albumin $(\mathrm{g} / \mathrm{dL})$ & $4.24 \pm 1.05$ & & $2.69 \pm 1.16^{*}$ \\
Zinc, $(\mu / \mathrm{L})$ & 138.31 & \pm 5.11 & $116.22 \pm 3.65^{*}$ \\
Vitamin C. $(\mathrm{mg} / \mathrm{dl})$ & $1.81 \pm$ & 0.24 & $0.64 \pm 0.38^{*}$
\end{tabular}

* Significantly different from control at $\mathrm{P}<0.05$.

\section{Discussion}

The level of serum albumin was depleted among the surgical wound patients when compared with the control. Serum albumin concentration has been used as a biochemical marker of nutritional status; it is one of the easiest parameters to measure and that which best reflects the state of visceral protein (Behzad et al., 2015). However, albumin is the major protein synthesized in liver. The long half-life and broad distribution in the body prevent nutritional changes from being reflected rapidly in albumin serum concentration. Some processes regulate plasma albumin concentration, including absolute rate of albumin synthesis and Fractional Catabolic Rate (FCR), among others. Albumin, the body's predominant serum-binding protein, has several important functions. Albumin comprises $75-80 \%$ of normal plasma colloid oncotic pressure and $50 \%$ of protein content. When plasma proteins, especially albumin, no longer sustain sufficient colloid osmotic pressure to counterbalance hydrostatic pressure, edema develops. Albumin transports various substances, including bilirubin, fatty acids, metals, ions, hormones, and exogenous drugs. One consequence of hypoalbuminemia is that drugs that are usually protein bound are free in the plasma, allowing for higher drug levels, more rapid hepatic metabolism, or both. Serum albumin level is an important prognostic indicator. Among hospitalized patients, lower serum albumin levels correlate with an increased risk of morbidity and mortality (Numeroso et al., 2008).

In this study, the level of zinc was significantly decreased in surgical wound patients when compared to control. This is in line with the work of Nnodim et al. (2014a) in which the level of zinc was reduced in sickle cell patients. Zinc ( $\mathrm{Zn})$ is an essential micronutrient which has an essential role in the functioning of hundreds of enzymes, in insulin metabolism and acts as an efficient antioxidant. It is considered important due to the fact that it plays a major role in the stabilization of insulin hexamers and the pancreatic storage of the hormone. The presence of a zinc deficiency in the body has also been suggested to contribute to the development of diabetes in some humans. Zinc itself may be a crucial element in insulin metabolism. Zinc is well-known as a powerful guardian against viral infections, and may also act to protect beta cells from destruction (Hambidge \& Krebs, 2007). Zinc plays an important role in the structure and function of biological membranes. It has been shown to have an antioxidant potential through the non-enzymatic stabilization of biomembrane and biostructures. The protective effects of zinc could be linked to its ability to reduce collagen accumulation in liver. It also exert critical physiological role in regulating the structure and function of cells. It is required for the adequate formation and function of the antioxidant enzyme: copper zinc superoxide dismutase and various 
metallothioneins. The metallothionein plays a role in the detoxification of heavy metals and stabilize membrane (Atakisi et al., 2009).

In the same vein, vitamin $\mathrm{C}$ was depleted among surgical wound patients when compared to control. This is in agreement with the work of Nnodim et al. $(2014 \mathrm{~b}, \mathrm{c})$ The results are consistent with the work Ray et al. (2007) who suggested that vitamin C may prevent the accumulation of sorbitol intracellularly by inhibiting the aldose reductase enzyme. Vitamin $\mathrm{C}$ an aqueous phase antioxidant has been reported to improve whole body glucose disposal in healthy subjects and in diabetic patients and animals (Mauro, 2006).

Vitamin C plays important role in reducing the blood glucose through decreasing the oxidative stress in different ways. It indeed reduces the damaging effect on the blood vessels and prevents the lipid peroxidation. In the same vein, it regulates nitric oxide synthase that generates the nitric oxide, a potent vasodilator that plays a key role in controlling the cardiovascular system. It also decreases the activity of $(\mathrm{NADPH})$ oxidase and (ROS) production, and regulates the antioxidant enzyme including superoxide dismutase and glutathione (Titus et al., 2004).

Vitamin $\mathrm{C}$ is an antioxidant substance soluble in water which keeps most of metal cofactors in reduction status. In physiological conditions, it appears in the form of dehydroascorbic acid and can react with amino groups and form schiff bases. By increasing the amount of vitamin $\mathrm{c}$ in the bloodstream, the amount of sorbitol may be lowered. Sorbitol is a harmful sugar when it accumulates, and its presence may lead to increased risk of diabetic complications such as retinopathy, neuropathy and kidney damage. In the case of surgical wound, vitamin c may play a role in improving the healing process (Ray et al., 2007).

\section{References}

Agarwal, R., Davis, J. L., \& Smith, L. (2008). Serum albumin is strongly associated with erythropoietin sensitivity in hemodialysis patients. Clin $J$ Am Soc Nephrol, 3, 98-104. https://doi.org/10.2215/CJN.03330807

Atakisi, O., Atakisi, E., \& Kart, A. (2009). Effects of dietary zinc and L-arginine supplementation on total antioxidants capacity, lipid peroxidation, nitric oxide, egg weight, and blood biochemic values in Japanese quails. Biol Trace Elem Res, 132(1-3), 136. https://doi.org/10.1007/s12011-009-8378-x

Behzad, H., Hassan, T., Karimollah, H., Mehdi, Y., \& Roghayeh, A. (2015). Low baseline serum albumin as a predictor of anemia in chronic hemodialysis patients. Caspian J Intern Med, 6(3), 161-164.

Coello, R., Charlett, A., \& Wilson, J. (2005). Adverse impact of surgical site infections in English hospitals. Journal of Hospital Infection, 60, 93-103. https://doi.org/10.1016/j.jhin.2004.10.019

Culver, D. H., Horan, T. C., \& Gaynes, R. P. (1991). Surgical wound infection rates by wound class, operative procedure, and patient risk index. National Nosocomial Infections Surveillance System. 
American Journal of $\quad$ Medicine, $\quad$ 152S-157S. https://doi.org/10.1016/0002-9343(91)90361-Z

Dao, C. N., Peters, P. J., \& Kiarie, J. N. (2011). Hyponatremia, hypochloremia, and hypoalbuminemia predict an increased risk of mortality during the first year of antiretroviral therapy among HIV-infected Zambian and Kenyan women. AIDS Res Hum Retroviruses, 27, 1149-1155. https://doi.org/10.1089/aid.2010.0345

Graham, S. M., Baeten, J. M., \& Richardson, B. A. (2007). A decrease in albumin in early HIV type 1 infection predicts subsequent disease progression. AIDS Res Hum Retroviruses, 23, 1197-1200. https://doi.org/10.1089/aid.2007.0065

Hambidge, K. M., \& Krebs, N. F. (2007). Zinc deficiency: A special challenge. J. Nutr, 137(4), 1101-1105.

Hunt, T. K., Hopf, H., \& Hussain, Z. (2000). Physiology of Wound healing. Adv Skin Wound Care, 13, 6-11.

Kaneko, J. J. (1999). In Clinical Biochemistry of Animal (4th ed., pp. 932-934). Kaneko, J.J. edition academic Press. Inc. New York.

Kuzuya, M. I. S., Enoki, H., Okada, K., \& Iguchi, A. (2007). Is serum albumin a good marker for malnutrition in the physically impaired elderly? Clin Nutr, 26, 84-90. https://doi.org/10.1016/j.clnu.2006.07.009

Mauro, S. (2006). The role of antioxidants in disease prevention. Medicine, 34(12), 533-535. https://doi.org/10.1053/j.mpmed.2006.09.007

Nnodim, J. K., Meludu, S. C., Dioka, C. E., Ihim, A., Onyemailoh, O. B., \& Obi, P. C. (2014c). Antioxidant vitamins and glycatedhaemoglobin status in sickle cell anaemia. Almeen J Med Sci, $7(2), 175-177$.

Nnodim, J. K., Meludu, S. C., Dioka, C. E., Onah, C., Ihim, A., \& Atuegbu, C. (2014a). Trace elements deficiency in patients with homozygous sickle cell disease. British Journal of Medicine \& Medical Research, 4(21), 3879-3883. https://doi.org/10.9734/BJMMR/2014/7489

Nnodim, J. K., Uzochukwu, O., Nwadike, C. N., Chilaka, U., \& Obi, P. C. (2014b). Alterations in antioxidant vitamins in prostate cancer patients. International Journal of Nursing Education \& Research, 1(1), 1-3.

Numeroso, F., Barilli, A. L., \& Delsignore, R. (2008). Prevalence and significance of hypoalbuminemia in an internal medicine department. European Journal of internal medicine, 19(8), 587-591. https://doi.org/10.1016/j.ejim.2007.04.029

Ray, D., Deshmukh, P., Goswami, K., \& Garg, N. (2007). Antioxidant vitamin levels in Sickle cell disease disorders. Natl Med J India, 99, 891-894.

Rivera, A. E., \& Spencer, J. M. (2007). Clinical aspects of full thickness wound healing. Clin Dermatol, 25, 39-48. https://doi.org/10.1016/j.clindermatol.2006.10.001

Tietz, W. (1976). Fundamental of Clinical Chemistry. In W.B Saunder Company Britain (pp. 422-429). 
Titus, J., Chari, S., Gupta, M., \& Parekh, N. (2004). Prooxidant and antioxidant status in patients of sickle cell anaemia. Indian J clin. Biochem, 19, 168-172. https://doi.org/10.1007/BF02894279

Velnar, T., Bailey, T., \& Smrkolj, V. (2009). The wound healing process: An overview of the cellular and molecular mechanisms. $J$ Int Med Res, 37, 1528-1542. https://doi.org/10.1177/147323000903700531

Waldrop, J., \& Doughty, D. (2000). Wound healing physiology, Acute and Chronic Wounds: Nursing Management (2nd ed., pp. 17-80). St Louis, MO, London: Mosby.

Zainab, A. H. (2013). Effect of vitamin c and zinc on some biochemical parameter in alloxan induced diabetic rabbits. Bas.J.Vet.Res, 12(1), 77-86. 